\title{
Biofertilizers: An Alternative for Sustainable Agriculture in the Amazon Region
}

\author{
Elson. J. S. da Silva ${ }^{1}$, Jéssy A. V. Senado ${ }^{1}$, Dênmora G. Araujo ${ }^{1}$, Gisele B. da Silva ${ }^{1} \&$ Telma F. V. Batista ${ }^{1}$ \\ ${ }^{1}$ Institute of Agrarian Sciences, Federal Rural University of Amazonia, Pará, Brazil \\ Correspondence: Jéssy A. V. Senado, Institute of Agrarian Sciences, Federal Rural University of Amazonia, \\ Belém, Pará, Brazil. Tel: 55-91-99387-4498. E-mail: jessysenado@gmail.com
}

Received: August 6, 2018

doi:10.5539/jas.v10n12p317
Accepted: September 6, $2018 \quad$ Online Published: November 15, 2018

URL: https://doi.org/10.5539/jas.v10n12p317

\begin{abstract}
Agricultural production plays a strategic role in Amazon, since it has economic and food-growing importance, but also represents a great highlight in the cultural and social scenarios. However, such theme still faces some challenges regarding the development of alternative methods capable of achieving sustainable productions, with quality and quantity, and yet with no harm to the natural resources. The Trichoderma fungus has become significant as a biological agent in agricultural species, presenting considerable answers to the development and protection of vegetables, and has also guaranteed the environmental preservation and food safety. Such issues considered, this study intends to guide small agricultural producers about the usage of Trichoderma fungi, emphasizing the agricultural species cultivation. The university extension program took place in four communities promoting workshops about the usage of the Trichoderma and other alternative biofertilizers. Each community was interviewed in an attempt to identify the main difficulties regarding a sustainable agricultural production. As a result, $75 \%$ of the communities still used chemicals in their fertilizing and plague control processes and did not use biological-origin products due to the lack of information on where to obtain them and how to use such items; only $25 \%$ had alternatives of biological defensives and merely $5 \%$ had any knowledge about the usage of biofertilizers like Trichoderma. Such findings evidence it is necessary to continue the extension program actions, focusing on their improvement and expansion, since they benefit society, economy and the environment of the Amazon region.
\end{abstract}

Keywords: Trichoderma fungi, environmental preservation, food safety, protection of vegetables

\section{Introduction}

Agricultural production plays a strategic role in Amazon, since it has economic and food-growing importance, but also represents a great highlight in the cultural and social scenarios, specially when it comes to employment opportunities in the production process of agricultural species for human consumption (Santos, 2010). However, such theme still has faced some challenges.

In the Amazon region there are approximately 600 thousand small-scale producers (Homma, 2011), and many of the systems used by them have dissapeared due to low productivity caused by soil sub-exploitation.

The profile observed in many local communities is still chracterized by a conventional system of felling and burning, whose producers are sub-informed about alternatives that enhance soil quality without damaging the environment and human health, considering that the usage of chemical products in agriculture is still a relevant factor in the reality of those local producers, mainly in the areas which are more distant from the city.

Considering such issues, there is need for the development of alternative methods aiming a sustainable production capable of producing in quantity and quality, with no damage to the natural resources and that also stimulates produtors permanence in the production fields.

In this context, the application of the Trichoderma fungus has appeared as a biological agent in agricultural species and has offered meaningful answers in the development and protection of vegetables, which garantees environmental preservation and food safety (Lucon, Chave, \& Bacilieri, 2014). Although it is a promising resource, it is still under-reported and subutilized by local producers, and that is one of the limiting fator for a more sustainable production. 
Trichoderma is a filamentous fungus classified in the Eumycota division, Deuteromycota subdivision, and is commonly found in all types of soil, specially those rich in organic matter, and lives in saprophytic manner or as a parasite of other fungi (Esposito \& Silva, 1998). Therefore, it plays an important ecologic function, since its participation in decomposition and mineralization of vegetal residues, which contributes to nutritional availability for the plants (Weeden, Shelton, \& Hoffmann, 2008).

The biofertilizers based on the referred fungus are extremely important in the scenario of agricultural production in Amazon, since it has direct impact in the vegetables' radicular system, thus promoting a more proeminent plant growth and vitality (Machado, Parzianello, Silva, \& Antoniolli, 2012). The Trichoderma bioagents improve the production performances and induce defense actions by the plant itself against pests, through proteins and phytoalexins which protect the plant against fungic infections (Howell, 1987; Saito et al., 2009).

Considering the exposed subject, this paper aims to guide small agricultural producers about the usage of the Trichorderma fungus as a biofertilezer, emphasyzing the cultivation of agricultural species.

\section{Method}

The referred work of university extension is composed of some voluntary Forest Engineering and Agronomy students from Federal Rural University of Amazonia (UFRA) and supporting professors, and takes place at the small producers communities in the amazonian territory in urban and rural zones of the Metropolitan Region of Belém, state of Pará, Brazil. Currently, the Project has already taken place in four communities - two in the urban zone and two in the rural zone-located in the cities of Ananindeua, Santa Bárbara e the Mosqueiro district.

Each community had its agricultural production areas visited, the groups being composed of approximately thirty families; by interviewing the producers it was possible to identify the main dificulties related to sustainable agricultural production.

Amongst the topics of the interview, it was possible to collect information regarding the following aspects: main product cultivated; product destination; subsistence or comercialization; soil productivity; frequency of visits from public organs to assist them; usage of any kind of chemical product; level of information about sustainable alternatives and the usage of biological agentes as an alternative in their cultivation; and interest in an sustainable production.

At every community, workshops took place with demonstrations, highlighting the importance and ways to use the Trichoderma bioferlizer and the production of alternative biofertilizers to their cultivation. At the end of the activity, the communities received 500g of Trichoderma rice, produced at the Federal Rural University of Amazonia by the Plants Protection Laboratory, as well as an illustrative folder containing general instructions about the biofertilizer, as a way to promote good agricultural practices which improve the production in a sustainable way.

Those university extension actions about awareness and incentive to the use of biofertilizers are a sustainable alternative for small producers ocurred weekly at the unities of production in each community and, so far, such project does not have financing, therefore the resources to execute the activities are paid by the students and voluntary professors.

\section{Results}

The mais products cultivated by the small products of the region are short-cycle species of great importance to local feeding according to Table 1 .

Table 1. Main species cultivated in four communities of small producers in the amazonian territory in the urban and rural zones of the Metropolitan Region of Belém-Pará-Brazil

\begin{tabular}{lll}
\hline Species & Common name & Type of use \\
\hline Solanum lycopersicum $\mathrm{L}$. & Tomato & Feeding \\
Cucumis sativus $\mathrm{L}$. & Cucumber & Feeding \\
Lactuca sativa L. & Lettuce & Feeding \\
Coriandrum sativum L. & Coriander & Feeding \\
Acmella oleracea $(\mathrm{L}$.$) R. K. Jansen$ & Jambu & Feeding \\
Allium schoenoprasum L. & Chive & Feeding \\
Brassica oleracea L. & Cole & Feeding \\
\hline
\end{tabular}


According to the interviews we can observe that this agricultural production has great importance to the community's subsistence, which means its destinated to local comsuption and also as an exchange product for other kinds of food. Besides, there is commercialization of these products, and one of the cooperative groups located in the city of Ananindeua has a partnership with the government so that their production is destined to public schools' luncheon preparation.

Those communities, located in both urban and rural zones, are connected to cooperative groups and, in some occasions, receive short courses, workshops and instructions about agricultural practices taught by some research intitutions, such as Brazilian Enterprise of Agriculture and Livestock (EMBRAPA) and also some organs as Technical Assistance and Rural Extension Company (EMATER).

However, it has been reported by some communities that the responsible government organs don't appear often enough at the production areas to subsidiate small producers.

The amazonian territory in which the Metropolitan Region of Belém is contained has a great quantity of small producers, which frequently avoids the few government professionals responsible for them to visit them more often.

Besides, many of those producers are located in distant, hard-to-access areas, which may be one the factors that limit a deeper knowledge about effective and sustainable alternatives to manage agricultural cultivations.

All of the agriculturists reported to have low-productivity soils, due mainly to the constant use of the soil and pests like cochineal, catterpillars, locusts, paquinha and fungic pathogens, which can all be controlled by the Trichoderma biofertilizers. Although they are small agriculturists', in those areas it is common for pests to appear, such as leafcutter ants, sucking insects and others, and these agricultural pests are a challenge to the vegetable production (Filho, Guimarães, \& Liz, 2009).

From all interviewed communities, $75 \%$ still maintained fertilization and pest control with chemical products and did not use biological origined products due to the lack of information about where to obtain and how to use them, only $25 \%$ have biodefensers alternatives and only $25 \%$ had knowledge about the Trichoderma biofertilizers usage. That small percentage of people who presented information about the importance of the fungus is also part of another group of agriculturists who are connected to the Federal Rural University of Amazonia through other institutional projects which promote sustainable agriculture in our region.

It is important to highlight that $100 \%$ of the producers interviewed presented an enormous interest in colaborating with sustainable agriculture by using biological alternative to promote their cultures growth and also replace chemicals utilized to the pest control for bio-origined products, like the Trichoderma.

\section{Discussion}

This substitution of chemicals by biologicals is of great importance specially to promote food safety to the community that consumes those foods, since the usage of such agrotoxicals dangerously exposes the consumers, the environment and the workers to chemical contamination by the product (Almeida, Carneiro, \& Vilela, 2009), whereas the biologically origined products do not threaten food safety and, in addition, contribute to the preservation of beneficial microorganisms in the soil, do not pollute the environment and maintain the biodiversity and ecossystem's balance (Araújo, 2011).

Studies about the usage of the Trichoderma fungus as a sustainable alternative evidentiate several advantages, due to its fundamental role in nutrition and development of the plant, colonize the radicular system thus protecting those plants against various pathogens, fight pests and diseases contributing to the reduction of agrotoxicals use, it can be pulverized in several species of agricultural interest and, because it a natural controlling device, the Trichoderma does not leave residue on the food and can also be utilized in the treatment of seed, which avoids diseases to affect plants at such phase (Anonymous, 2017).

There is an increasing concern about sustainable agricultural production due to the necessity of meeting the fundamental requirements of its concept: economically viable, environmentally correct and socially fair (Trecenti, 2009). Thus, the presentation of biofertilizers to the small producers has an essential role to colaborate in that search.

In face of the stringency small producers live, university extensions is necessary to act assisting the community, because being in touch with the local, regional or national reality, the university can exchange knowledges and refresh its own structure, its actions and creativity, in order to assist society and avoiding knowledge to only have scientific importance (Nunes \& Silva, 2011), thus improving life quality and ensuring a sustainable production in food safety and environmental preservation. 
Currently the challenge we face to be able to attend the community's deman is exactly the production of the Trichoderma rice biofertilizer in a larger scale so it can be comercialized and supply the demand of those producers.

\section{Conclusion}

In face of the lack of information about the biofertilizer and the producers' need of sustainable alternatives, it is necessary that we continue the action explained above, improved and enlarged, in order to further beneficiate society, economy and environment, and so to allow that the knowledge acquired at the University not only presents scientific value, but also exists to assist the community.

\section{References}

Anonymous. (2017). 9 motivos para usar fungos Trichoderma na agricultura orgânica. Retriever from http://agronews.tv.br/9-motivos-para-usar-fungo-trichoderma-na-agricultura-organica

Almeida, V. E. S., Carneiro, F. F., \& Vilela, N. J. (2009). Agrotóxicos em hortaliças: Segurança alimentar, riscos socioambientais e políticas públicas para promoção da saúde. Tempus. Actas em Saúde Coletiva, 4(4), 84-99.

Araújo, E. (2011). Agricultura biológica: Quais suas vantagens? Retriever July 8, 2017, from http://agricultura-biologica.blogs.sapo.pt/tag/vantagens/desvantagens

Esposito, E., \& Silva, M. (1998). Systematics and environmental application of the genus Trichoderma. Critical Reviews in Microbiology, 24(2), 89-98.

Filho, M. M., Guimarães, J. A., \& Liz, R. S. (2009). Recomendações para controle de pragas em hortas urbanas. Circular Técnica $n^{\circ}$ 80. Empresa Brasileira de Pesquisa Agropecuária, Brasília.

Homma, A. K. O. (2011). Agricultura na Amazônia: O futuro é plantar sem derrubar. In A. L. Val, \& G. M. Santos (Eds.), GEEA: Grupo de Estudos Estratégicos Amazônicos (pp. 13-64). Manaus: Editora INPA.

Howell, C. R. (1987). The Role of mycoparasitism in the biological control of Rhizoctonia solani by Gliocadium virens. Phytopathology, 77, 992-994.

Lucon, C. M. M., Chaves, A. L. R., \& Bacilieri, S. (2014). Trichoderma: O que é, para que serve e como usar corretamente na lavoura (1st ed.). São Paulo: Instituto Biológico.

Machado, D. F. M., Parzianello, F. R., Silva, A. C. F., \& Antoniolli, Z. I. (2012). Trichoderma no Brasil: O fungo e o bioagente. Revista Ciências Agrárias, 35(1), 274-288.

Nunes, A. L. F., \& Silva, M. B. C. (2011). A extensão universitária no ensino superior e a sociedade. Minas Gerais. Retrieved July 10, 2017, from http://www.uemg.br/openjournal/index.php/malestar/article/viewFile/ $60 / 89$

Saito, L. R., Sales, L. L. S. R., Martinckoski, L., Royer, R., Ramos, M. S., \& Reffatti, T. (2009). Aspectos dos efeitos do fungo Trichoderma spp. no biocontrole de patógenos de culturas agrícolas. Pesquisa Aplicada \& Agrotecnologia, 2(3).

Santos, S. R. (2010). Agricultura familiar no Brasil. Retrieved July 8, 2017, from http://www.webartigos.com/ artigos/agricultura-familiar-no-brasil/31006/

Trecenti, R. (2009). Sistemas sustentáveis de produção. Retrieved July 9, 2017, from http://www.diadecampo. com.br/zpublisher/materias/Materia.asp?id=20606\&secao=Colunas\%20Assinadas

Weeden, C. R., Shelton, A. M., \& Hoffman, M. P. (2008). Biological control: A guide to natural enemies in North America. Retrieved July 9, 2017, from https://nysaes.cals.cornell.edu/ent/biocontrol/predators/ predtoc.html

\section{Copyrights}

Copyright for this article is retained by the author(s), with first publication rights granted to the journal.

This is an open-access article distributed under the terms and conditions of the Creative Commons Attribution license (http://creativecommons.org/licenses/by/4.0/). 